\author{
Britt Oda Fosse \\ Institutt for lcererutdanning og skoleforskning \\ Universitetet i Oslo \\ E-post: $\underline{\text { b.o.fosse@ils.uio.no }}$
}

\title{
Transformering av kunnskap mellom campus og skole i lærerutdanningen
}

\begin{abstract}
Sammendrag
Til tross for lærerutdanningers mangeårige arbeid med å finne innovative løsninger som skaper gode sammenhenger mellom campuskonteksten og skolekonteksten, etterlyser larerstudentene fortsatt en bedre sammenheng i studiet. Det som kjennetegner metodene i mange lererutdanninger er at de bygger på ideen om laring for praksis. Dette innebcrer i stor grad forventninger om at studentene transformerer kunnskap fra campus til undervisning og refleksjon i skolen. Mye tyder på at lcererstudentene fär lite hjelp $i$ denne prosessen. Studier om koherens - eller sammenheng - $i$ lcererutdanningen knyttes sjelden til at lcererutdanning kan innebcere et leringsproblem. Hensikten med denne artikkelen er å undersøke de laringsutfordringer studenter har når kunnskap skal transformeres mellom de to kontekstene. Tanken er at en forståelse for lcererstudenters lcering på denne måten kan bidra inn i arbeidet med å videreutvikle metoder i lererutdanningen som kan lette transformeringsprosessene. Artikkelen er tematisk og drøftes i lys av sosiokulturelle perspektiver på laring og utvikling med vekt på begrepene "overføring" og "transformering". Videre drøftes problemstillingen i lys av studier av læererstudenters interaktive læringsprosesser.
\end{abstract}

Nøkkelord: lcererutdanning, lcererstudenters lceringsprosesser, transformering av lcering.

\begin{abstract}
Despite innovative work on bridging the gap between campus activities and classroom activities, student teachers ask for more coherence in their education. What characterizes the different teacher education innovations is that they are mainly based on the idea that students construct knowledge for practice. In these scenarios, teacher education programmes rely on the students' ability to transform knowledge from activities at campus into teaching and reflection in their practice schools. The student teachers seem to get little or no help in these transformational processes. When studying coherence in teacher education, researchers rarely draw the attention to teacher education as a learning problem. This article discusses the problems inherent in transforming knowledge between contexts in teacher education, by focusing on the concepts of "transfer" and "transformation" and on studies of student teachers' interactive learning processes. The idea is that knowledge about how student teachers learn in different contexts and how the knowledge is transformed between contexts is necessary to develop a coherent teacher education. The paper is thematic and the research question will be discussed in light of a socio-cultural perspective on learning and development, relevant literature, and studies regarding theories of learning and transformation. The research question will be further discussed in light of qualitative studies on teacher students' interactive learning processes.
\end{abstract}

Keywords: teacher education, learning, student teachers learning processes, learning as transformation 


\section{Innledning}

Mange lærerutdanninger i Norge har de siste 15 årene utviklet og gjennomført strategier og metoder for å lette lærerstudenters transformering av kunnskap mellom campus og skolekonteksten, og mye tyder på at de grepene som er gjennomført har gjort det enklere for studentene å se sammenhengen mellom de to kontekstene (Klette \& Hammerness, 2016; Lillejord \& Børte, 2014; Ludvigsen \& Hoel, 2002; Rindal, Lund, \& Jakhelln, 2015). En sentral løsning i dette arbeidet har vært å utvikle partnerskap mellom lærerutdanningene ved universiteter/høyskoler og praksisskolene (Darling-Hammond, 2008; Korthagen, 2008; Lambert, 2003; Lillejord \& Børte, 2014), og å utvikle nye metoder som kan lette transformeringsarbeidet for lærerstudentene. Eksempler på det siste er bruk av case-metodikk, arbeid med "core-set-of-practices", grenseobjekter og "det tredje rom” (Edwards, 2010; Grossman, Hammerness, \& McDonald, 2009; Hauge, 2002; Klette \& Hammerness, 2016; Lillejord \& Børte, 2014; Rindal, Lund, \& Jakhelln, 2015).

Det som kjennetegner metodene er imidlertid at de i stor grad initieres og utvikles av lærerutdannere på campus og at det blir studentenes ansvar å transformere og bruke kunnskapen i skolen. Det som ofte skjer, er at det blir lærerstudentenes ansvar å informere skolene om hva som gjelder som kunnskap ved universitetet eller høyskolen. I denne prosessen transformerer ofte studenten sin individuelle kunnskap og forståelse (Afdal, 2014; Childs, Edwards, \& McNicholl, 2014) og tilpasser seg videre til skolens måte å forstå og snakke om undervisning på (Edwards \& Protheroe, 2003; Fosse, 2011; Ottesen, 2006; Sundli, 2001).

Det er mye som tyder på at studentene, til tross for innovativt arbeid i lærerutdanningen, fortsatt opplever at de går ut og inn av to forskjellige verdener og etterlyser større sammenheng i studiet (Lillejord \& Børte, 2014; NOKUT, 2006; 2013). I følge Lillejord og Børte (2014) er det behov for nytenkning når det gjelder partnerskapsmodeller, hvor blant annet studentenes læring blir satt i sentrum.

De studiene det refereres til ovenfor har i hovedsak satt søkelyset på overordnede strukturelle og organisatoriske endringer og reformer i lærerutdanningen og på lærerstudenters rapporterte forståelse av egen læring i spenningsfeltet mellom teori og praksis. Det er få studier som ser på hvordan lærerstudenter konstruerer kunnskap og hva som skjer med denne kunnskapen i transformeringsprosessen mellom campus og skole (Haug, 2010; Karlsen, 2003).

Hovedmålet med denne artikkelen er å bidra med forståelse for de læringsutfordringer lærerstudenter har. Tanken er at innsikt i lærings og transformeringsprosesser er grunnleggende når partnerskapsmodeller og metoder som kan lette disse prosessene i lærerutdanningen, skal utvikles. Artikkelen er tematisk og tar utgangspunkt i sosiokulturelle teorier om læring og 
utvikling. Den handler i hovedsak om pedagogikk i norsk offentlig lærerutdanning, og ser på kvalitative studier av lærerstudenters interaktive læringsprosesser ved en praktisk-pedagogisk utdanning (PPU). Med dette som utgangspunkt drøftes følgende problemstilling:

Hvordan kan vi, med utgangspunkt i teorier og studier knyttet til læring, forstå lærerstudenters utfordringer med å transformere kunnskap mellom campus og skole?

\section{Gjennomgang av relevant litteratur og forskning}

\section{Søkeprosessen}

Temaet for denne artikkelen har sitt utgangspunkt i arbeidet med en doktoravhandling (Fosse, 2011). I lys av at denne artikkelen utforsker lærerstudenters læring og transformering av læring og videre støtter seg til et sosiokulturelt på læring er det søkt etter studier som sier noe om lærerstudenters situerte læringsprosesser i lys av disse perspektivene. Det er søkt etter litteratur som drøfter og forklarer ulike perspektiver på læring og transformering av læring. Relevant litteratur og empiriske studier som kan belyse problemstillingen er hentet fra flere kilder; i databaser (ERIC og Google Scolar), i håndbøker (Studying Teacher Education: The Report of the AERA Panel on Research and Teacher Education, 2005 og Handbook of Research on Teacher Education: Eduring Questions in Changing Contexts, 2008), i pensumlister fra doktorgradskurs ved Universitetet i Oslo om menneskers læring og utvikling og i relevante bøker og artikler presentert i lærerutdanningsmiljøer nasjonalt og internasjonalt.

Søkeord som "kognitive*, kulturhistoriske* og sosiokulturelle* læringsteorier”, "overføring*, transformering* av kunnskap”, "overføring*, transformering* av kunnskap mellom teori praksis i lærerutdanningen”, «teoripraksis problematikken i lærerutdanningen”, og videre "cognition”, "cognitive* socio-cultural* culture-historical* learning-theories", "transfer*, transportation*, transformation* of learning/knowledge", "theory-practice dilemma* problems* teacher eduction*” for å nevne de viktigste. Det er søkt både med norske og engelske ord og uttrykk. På norsk ble søkeordene utvidet med ord som "lærerstudenter* interaktive* læringsprosesser", "transformering* transformasjon* overføring* læring* i lærerutdanningen”. Søket ga få resultater som gikk spesifikt på lærerstudenters interaktive og situerte læringsprosesser. Av relevante søkeresultater falt valget på studier gjort ved Universitetet i Oslo, som viser hvordan mening utvikles i aktiviteter i pedagogikkfaget på campus og i veiledningen i skolens praksis. Disse studiene støtter seg til interaksjonsanalytiske metoder. Søkeordene ble både brukt i søk på nettet og i bøkers innholdsfortegnelse, referanselister og emneindeks. 
Artikkelen hevder ikke å ha gjennomført en altomfattende og inngående gjennomgang av potensielt relevant litteratur, men mener at det som er valgt viser et representativt bilde av tilgjengelige kilder som belyser utfordringer med å transformere kunnskap mellom campus og skole. Artikkelen trekker på forskning med et spesifikt læringssyn og med spesifikt fokus. Dette begrenser selvsagt søket og valget av litteratur. De dypdykk som er valgt, av lærerstudenters læringsprosesser, er få og gjort ved egen institusjon. I følge Borko mfl. (2008) har imidlertid forskning i lys av sosiokulturelle teorier i sin kjerne søken etter lokal mening, og de lokale studiene er således ett av flere lokale bidrag som til sammen kan gi et kunnskapsgrunnlag det kan generaliseres ut fra.

\section{Fremtredende perspektiver}

I søket med referanse til de overordnede perspektivene på læring og transformering er det spesielt en diskusjon på slutten av 1980-tallet og begynnelsen 2000-tallet som trer fram som aktuell litteratur. Flere forskere (for eksempel Anderson, Greeno, \& Simon, 2000; Packer \& Goicoechea, 2000; Wertsch, 1998) drøftet det de mener er et unaturlig skille mellom individ og samfunn innenfor sosial eller human forskning, og trekker frem de sosiokulturelle og kognitive perspektivene som eksempler på motsatser det bør bygges bro mellom.

Søkeprosessen brakte også fram diskurser om hvilken kunnskap og erfaringer som gjør lærerstudenter og lærere best egnet til å gi god undervisning, samt hvor og hvordan denne kunnskapen best konstrueres (Cochran-Smith \& Lytle, 1999; Fenstermacher, 1994). For eksempel, hvem produserer kunnskap om undervisning, er det forskeren, læreren eller begge? Hvordan overføres eller transformeres kunnskap, fra universitetet til skolen eller omvendt, eller i gjensidighet?

For å understreke artikkelens teoretiske perspektiv vises det her til CochranSmith og Lytles (1999) studier knyttet til læreres læring. De skiller mellom tre ideer om hvordan kunnskap om undervisning konstrueres: Kunnskap for praksis, kunnskap i praksis og kunnskap fra praksis. Kunnskap for praksis ser på nødvendigheten av at lærerstudenter utvikler en kunnskapsbasis som de først og fremst får fra forskning produsert ved universitetet. Undervisning innenfor dette perspektivet er forstått som en transformering av teoretisk kunnskap til praksis i klasserommet. Cochran-Smith og Lytle (1999) hevder at det å opprettholde kunnskap for praksis som overordnet, eller gi dette høyere status enn den praktiske kunnskapen, er med på å forsterke avstanden mellom de to praksisene og mellom praktikere og forskere. Kunnskap i praksis har som utgangspunkt at undervisning i stor grad er en spontan og uforutsigbar aktivitet situert og konstruert i møte med det som skjer i klasserommet. Innenfor dette perspektivet ligger den kunnskapen lærere og lærerstudenter trenger fra eksemplarisk undervisning gjort av erfarne lærere. Kunnskap oppnås gjennom erfaring, og 
gjennom refleksjon over og undersøkelser av praksis. Innenfor den tredje ideen, om kunnskap fra praksis tenker man at lærere genererer lokal kunnskap, ved å jobbe innenfor og samtidig forske på egen praksis. Denne ideen står i kontrast til ideen om at det finnes to distinkte typer kunnskap om undervisning, altså teoretisk og praktisk kunnskap. De involverte lærer gjennom å delta i systematisk og intensjonell forskning av alle sider ved undervisningen. Målet er å forstå, sette ord på og endre undervisningen, og samtidig problematisere egen kunnskap og praksis.

I Norge har lærerutdanningen tradisjonelt vært styrt av ideen om kunnskap for praksis (Aasen, 2008; Smebye, 2010; Sundli, 2003). Denne tenkningen preger også litteraturen og forskningen det vises til i denne artikkelen. Artikkelen står dermed i fare å fremheve ideen om kunnskap for praksis som den vesentligste. Dette er ikke hensikten. En av hensiktene med artikkelen er å vise at arbeidet med å utvikle lærerutdanningen også innebærer å stille spørsmål ved hvor og hvordan kunnskap om undervisning konstrueres.

I lys av et sosiokulturelt syn på læring utgjør teoretisk kunnskap, praktisk kunnskap og erfaringer en integrert del av lærerstudentenes representasjoner, i alle situasjoner (Vygotsky, 2001; Wertsch, 1998). Det innebærer at det er unaturlig å bruke begrepet "teori og praksis" om det som skjer henholdsvis på universitetet/høyskolen og i skolens praksisperiode. I stedet for å bruke begrepet "teori og praksis» bruker jeg i denne artikkelen begrepet "campus og skole” som betegnelse på hovedkontekstene i lærerutdanningen. Utrykket "mellom kontekster” betyr her i prinsippet at kunnskap er i bevegelse begge veier.

\section{Kunnskap for praksis}

Tradisjonelt har teoretisk og abstrakt kunnskap blitt sett på som mer verdt enn den praktiske. Pedagogikkfagets rolle var å produsere teorier om praksis og for praksis (Korthagen, 2008). Imidlertid er det mye som tyder på at pedagogikken ikke har innfridd i denne sammenhengen. I følge Haug (2008) har den akademiske pedagogikken (i norsk kontekst) bare i liten grad vært opptatt av skole, lærerutdanning og lærerprofesjon. Dette har ført til at orienteringen om skole i pedagogikkfaget har vært avhengig av den enkelte som underviste i faget, noe som igjen har hindret lærere i å utvikle et felles språk de kan snakke om skolen innenfor. Samtidig vet vi at lærerstudentene i stor grad opplever skoleerfaringene som mer verdifulle enn de akademiske erfaringene (Korthagen, 2008; NOKUT, 2006; 2013). Studier gjort av lærerstudenters aktiviteter i skolekonteksten viser blant annet at det som dominerer veiledningen i skolen, er fortellinger om "gjøringer" i klasserommet og i liten grad begrunnelser og refleksjon over disse (Edwards \& Protheroe, 2003; Fosse, 2011; Ottesen, 2006; Sundli, 2001). Videre viser studier at lærerstudenter i stor grad påvirkes av praksislæreres klasseromatferd og adopterer deres hverdagslige måte å snakke på. Det betyr ikke at lærerstudenter ikke er opptatt av forskning og teorier om elevers læring og utvikling, men at de opplever manglende yrkesrelevans i 
studiet, og liten mulighet til å bruke kunnskapen og begrepene de har utviklet i campuskonteksten i skolen (Haugan, 2014; Smeby, 2010). Vi står med andre ord overfor dilemmaer knyttet til lærerstudenters læring som tydelig viser en spenning mellom ulike læringsarenaer eller kontekster som har ulikt innhold og ulike interesser.

I denne artikkelen knyttes denne manglende sammenhengen mellom kontekster - her omtalt som koherensproblemet i lærerutdanningen - til et læringsproblem, nærmere bestemt til utfordringer lærerstudentene har med å transformere kunnskap mellom kontekster. Denne artikkelen antyder videre at lærerutdanningen bør bli bedre til å hjelpe studentene i transformeringsprosessene og at det derfor er avgjørende å vite noe om hvordan lærerstudenter lærer i de ulike kontekstene og hvordan kunnskap transformeres mellom kontekster. I det følgende vil dette problematiseres i lys av teorier om læring og transformering av læring.

\section{Læring og transformering av kunnskap - et spørsmål om læringssyn?}

Det tradisjonelle skillet mellom teori og praksis, som presentert ovenfor, knyttes av flere til et dualistisk perspektiv på læring som innebærer en forståelse av individ og verden (mind and world) som to atskilte verdener (Lave \& Wenger, 1991; Packer \& Goicoechea, 2000; Säljö, 2006). Læring som overføring sto sentralt i denne sammenhengen.

Overføring som begrep betydde overføring eller transportering av kunnskap mellom situasjoner og problemer. Det var spesielt kognitive perspektiver som representerte dette synet. Fakta, prinsipper og holdninger overføres eller transporteres til individet, som bringer fram kunnskapen i passende situasjoner. Innenfor et kognitivt læringsperspektiv har en antatt at individet ganske uproblematisk bringer med seg kunnskap fra en situasjon til en annen. Denne tenkningen har vært med på å prege skolen siden dens opprinnelse, hevder Säljö (2006).

Et bærende prinsipp i kognitiv teori er menneskets naturlige tendens til å tolke, skape system i og ordne oppfatninger om verden rundt seg. De kognitive perspektivene la vekt på å utforske menneskets indre prosesser mellom påvirkning og handling (Gardner, 1985), det vil si menneskers intellektuelle funksjoner, som læring, hukommelse, tenkning og problemløsning. Forskningen dreide seg som oftest om isolerte forsøk på enkeltindivider. Man mente at studier av læringsprosesser ikke måtte påvirkes av eksterne faktorer som følelser, historie, kultur og kontekst siden disse utgjør skiftende variabler som kan virke inn på individets handlinger (Vera \& Simon, 1993). Menneskelig tenkning ble ansett som en indre og individuell prosess. De sosiale aspektene ved kognitiv læring utelukkes i første omgang, og kan kun trekkes inn når man har oppnådd konsistent kunnskap om indre prosesser (Gardner, 1985). Jean Piaget (1896-1980) var en betydelig bidragsyter på dette forskningsfeltet. 
Vygotsky (1896-1934) utviklet en kulturhistorisk teori som en motsats mot det han kalte krisen innenfor psykologien i begynnelsen av 1920-årene, nettopp fordi synet på menneskelig bevissthet og tenkning var preget av en individualistisk forutinntatthet om tenkning som noe privat, som kun en indre prosess. Vygotsky (1978) kritiserte spesielt Piagets syn på kognisjon, og hevdet at menneskelig bevissthet utvikles først i fellesskap mellom mennesker, og deretter som egenskap i det enkelte mennesket. Læringsprosesser har videre en materiell forankring, hvilket betyr at individer handler i forhold til potensielle felles "objekter", eller problemområder. Dette innebærer at læring er prosesser som retter seg mot å anvende ulike former for tegn, symboler og verktøy i sosiale aktiviteter. Innenfor dette perspektivet er læring styrt av både indre og ytre prosesser, der det sosiale har størst betydning for læring. Redskapene for de høyere psykologiske prosessene er ikke utviklet av barnet selv, men er deler av den kulturen som omgir barnet. For Vygotsky er språket det viktigste redskap for læring. De psykologiske prosessene som styrer bruken av ord, forandres først og fremst gjennom samfunnsmessige faktorer.

\section{Transformering av kunnskap mellom kontekster}

Diskusjonen Vygtosky startet på 1920-tallet, ble hentet opp igjen på 1980-tallet, av Lave og Wenger. De utviklet et situert perspektiv på læring, et perspektiv som i stor grad var med på å sette i gang en ny diskusjon om hvordan vi kan forstå læring og overføring av kunnskap. I følge Lave og Wenger (1991) innebærer læring å bli et fullverdig medlem, deltaker og person i et samfunn. Læring involverer hele personen med vekt på gjensidig relasjonell avhengighet mellom aktør og verden, virksomhet, mening, kognisjon, læring og innsikt (Lave \& Wenger, 2003). Læring er således en prosess som finner sted i en deltakelsesramme, ikke kun i en individuell bevissthet.

Diskusjonen som utviklet seg handlet om hvorvidt de kognitive og de sosiokulturelle perspektivene på kunnskap og læring kunne forenes innenfor forskning og utdanning, og ble i stor grad en diskusjon der man utfordret dualismen mellom individ og samfunn og mellom teori og praksis. I denne diskusjonen ble begrepet overføring, forstått som transportering av kunnskap fra en person til en annen, ensbetydende med et dualistisk syn. Diskusjonen dreide seg både om epistemologiske spørsmål, det vil si som søker etter svar på hvordan man oppnår kunnskap, og om ontologiske spørsmål, som søker svar på hvordan verden faktisk ser ut og på vår væren-i-verden. Diskusjonen gikk videre på hvordan man kunne leve i spenningsfeltet mellom to så ulike perspektiver. Noen hevdet at det var vanskelig å forene de to synene (Packer \& Goicoechea, 2000), mens andre mente at man burde søke etter en måte å «live in the middle» (Wertsch, 1998). Andre hevdet at begge perspektivene tilbyr komplementære analyser av læring i utdanning (Andersen mfl., 2000), og andre igjen at det er umulig å lage et klart skille mellom de to hovedretningene i læringsteorien (Sfard, 1998). 
Packer og Goicoechea (2000) hevdet at de kognitive og sosiokulturelle perspektivene på kunnskap og læring har ulike ontologiske syn, og at det vil være vanskelig å forene det ontologiske perspektivet vi finner i et dualistisk syn på verden med et antidualistisk syn. Ifølge Packer og Goicoechea (2000) handler læring om transformering der vi både utvikles av og selv utvikler verden. Den kunnskapen vi har, overføres ikke direkte fra en sitasjon til en annen, som en kopi som skal passe inn i noe nytt. Kunnskapen konstrueres av mennesker og transformeres eller forandrer seg avhengig av situasjonen den oppstår i. Mennesket har på denne måten påvirkning på omgivelsene, og er ikke passive mottakere av sann og objektiv kunnskap.

Sfard (1998) hevder at overføringsmetaforen krysser grenser mellom det vitenskapelige og det hverdagslige og blir betydelige begreper for hvordan vi forstår fenomener. Det er derfor umulig å lage et klart skille mellom de to hovedretningene i læringsteorien, de kan ikke ekskludere eller utelukke hverandre. Sfard (1998) unngår overføringsmetaforen ved å konstruere to nye metaforer: tilegnelsesmetaforen (the Aquisition Metaphor [AM]) og deltakelsesmetaforen (the Participation Metaphor [PM]) og hevder at all diskurs om læring er fanget mellom disse to metaforene. I likhet med Packer og Goicoecheas (2000) hevder hun at AM og PM er ontologisk av natur og trekker på to helt ulike svar på spørsmålet om hva læring er, men at dikotomien ikke er kontroversiell når det kommer til å definere læring, og heller hviler på ulike visjoner om læringsmekanismer. Både det kognitive og det sosiokulturelle synet på læring innehar individuelle og sosiale læringsprosesser sett fra et utdanningsperspektiv, hevder Sfard (1998). Hun spør blant annet om det ikke skal være lov å snakke om at vi bringer med oss noe direkte fra en situasjon til den annen, eller om vi tør nekte for at ting repeteres eller gjentar seg selv når vi beveger oss fra situasjon til situasjon.

Sfard (1998) finner altså en løsning på de kognitive og sosiokulturelle perspektivene ved å kvitte seg med metaforen «overføring» men ikke selve innholdet i det. Hun beveger seg bort fra de rent forskningsmessige dilemmaene og ser innholdet i lys av det mer hverdagslige. Hun legger med dette grunnlaget for å forstå de ulike teoretiske synene i lys av den oppgaven lærerstudentene står overfor i den profesjonelle rollen de skal virke i, nemlig at læring både handler om sosiale og individuelle prosesser.

Eraut (2004) studerte, i lys av sosiokulturelle teorier, overføring og transformering som begreper i profesjonelle praksiser, og brukes her som kilde for å belyse tematikken ytterligere. Han var opptatt av hvordan kunnskap transformeres mellom profesjonelle kontekster, som for eksempel lærerutdanningen og definerer overføring som: ”The learning process involved when a person learns to use previously aquired knowledge/ skills / competence / expertise in a new situation” (Eraut, 2004, s. 58). Han trekker på Lave og Wengers teorier om praksisfelleskap, men kritiserer dem samtidig for ikke å være opptatt av at deltakerne også er deltakere i andre sosiale grupper, og at det 
de har lært andre steder ikke er en del at det situerte her og nå. Overføring mellom kontekster foregår ifølge Eraut (2004, min oversettelse) i fem trinn som alle er knyttet sammen. I denne prosessen vil studenten:

1. Trekke ut potensiell relevant kunnskap fra konteksten studenten kommer fra.

2. Jobbe med å forstå den nye situasjon (gjøres ofte gjennom uformelle sosiale prosesser).

3. Jobbe med å kjenne igjen kunnskap og ferdigheter som er relevante.

4. Transformere relevant kunnskap og ferdigheter slik at de passer inn i den nye situasjonen.

5. Integrere ny/transformert kunnskap og ferdigheter med annen kunnskap og ferdigheter med den hensikt å tenke, handle eller kommunisere i den nye situasjonen.

Eraut (2004) redefinerer med dette overføringsbegrepet og plasserer det innenfor et sosiokulturelt perspektiv på læring der både individuelle og sosiale prosesser interagerer. Samtidig ser vi at begrepet «transformering» blir en del av overføringsprosessene.

Earut (2004) hevder imidlertid at høyere utdanning er mest interessert i å overføre en kunnskap som er tatt for gitt, og derfor først og fremst vil forholde seg til trinn 1 og 3 . Videre hevder han at praksisplassen vil gi noe oppmerksomhet til trinn 3, og ta trinn 2 for gitt. Dette innebærer blant annet at det forventes at kunnskap fra høyere utdanning er "ferdig til bruk". Videre hevder Eraut (2004) at begge praksisene ikke bare ignorerer de store utfordringene som ligger i trinn 4 og 5 , men benekter eksistensen av dem, altså at selve transformasjonsprosessen ignoreres og at ingen tar ansvar for den. Eraut (2004) hevder videre at, "Since transfer is a social process as well as an individual process, this lack of preparedness is best described as disastrous" (s. 59). Han understreker også i nyere litteratur (Eraut, 2014) at dette er et stort problem for utvikling av profesjonell læring.

Oppsummert viser litteraturen at synet på læring og delaktighet i egne læringsprosesser har endret seg, og at dette får konsekvenser både for forskningsmetodene som brukes for å studere læring og utvikling, og for hvordan vi legger til rette for læring i undervisningssituasjoner. Diskusjonen som utviklet seg på 1980-tallet var i stor grad et oppgjør med den kognitive tradisjonen og dens syn på overføring som en direkte og ofte uproblematisk transport av kunnskap fra en kontekst til en annen. I et situert eller sosiokulturelt perspektiv var oppfatningen at kunnskap transformeres og forandrer verden rundt oss (Packer \& Goicoechea, 2000). Samtidig ble læring anerkjent for å handle om både sosiale og individuelle prosesser og om overføring og transformering (Eraut 2004; Sfard, 1998). Når det dreier seg om lærerstudenters læring er det dermed ikke mulig å lage et klart skille mellom de to 
hovedretningene innenfor læringsteorier, de kan verken ekskluderes eller utelukke hverandre.

\section{Læring i og mellom kontekster i lærerutdanningen. Studier av læringsprosesser}

Basert på ovennevnte teorigjennomgang, hevder jeg i denne artikkelen at en innsikt i lærerstudenters læringsprosesser kan bidra til å forstå hva som skjer når de beveger seg mellom campus og skolen. I det følgende presenteres studier gjort ved Universitetet i Oslo (Fosse, 2011; Jahreie 2010; Ottesen, 2006; Ottesen \& Jahreie, 2010a, 2010b) som kan belyse dette. Disse studiene tar utgangspunkt i sosiokulturelle forskningsmetoder. Formålet med en sosiokulturell forskningsmetode, er å forstå hvordan mentale funksjoner er relatert til en kulturell, institusjonell og historisk kontekst (Wertsch, 1998). Tidligere studier viser at sosiokulturelle forskningsmetoder har fungert som et viktig vindu til lærerstudenters læringsprosesser (Borko, Whithcomb, \& Byrnes, 2008; Cochran-Smith \& Demers, 2008; Howard \& Aleman, 2008).

De studiene som blir presentert her, har analysert dialoger mellom studenter, mellom studenter og lærere på campus, samt mellom studenter og veiledere i skolen. Studiene bruker interaksjonsanalytiske metoder i analysene av dialoger i lærerutdanningen, Basert på audio- eller video opptak av dialogene. Fokus i studiene er på hvilke redskaper som til tilbys i de ulike situasjonene og hvordan redskaper, både språklig og fysiske, får betydning i lærerstudentenes kunnskapsutvikling i de ulike kontekstene.

I den første studien, så Ottesen (2006) på lærerstudenters læring i skolekonteksten. Hun fulgte et utvalg studenter gjennom det ettårige læringsutdanningsløpet PPU. Studien hadde som overordnet mål å forstå hvordan lærerstudenter seg imellom og med praksisveileder utviklet sin praksisidentitet. Fokus i analysen var på hvordan dialogen konstituerte seg og kom til syne i situasjonen, hvordan kunnskap ble rekontekstualisert og hvilke begrepsmessige og praktiske redskaper som ble tatt i bruk i dialogen. Ottesens (2006) analyser viste at studentene tilpasset seg skolenes institusjonelle språk når de konstruerte sin identitet som lærere. Det bildet som dominerte veiledningen, var fokusering på undervisningens rutiner mer enn på lærerstudenters læring. De utviklet med andre ord sin identitet, og sin individuelle måte å gjøre ting på, innenfor den sosiale og kulturelle praksisen de deltok i. Imidlertid påpeker Ottesen (2006) at institusjonelle tradisjoner ikke kan ses som forsterkende og stabile, men som fleksible og utviklende. Hun konkluderte med at til tross for partnerskap, var avstanden mellom universitetet og skolene stor.

I en annen studie, studerte Jahreie (2010) bruk av case i teoriundervisningen på campus for å forstå hvordan lærerstudenter i fellesskap konstruerte mening om teori gjennom bruk av case. Casen var problemorientert og skulle fungere som et gjensidig samarbeidsprosjekt mellom universitetet og skolene. Data var 
hentet fra to studentgrupper over en periode på tre uker (9 x 45 minutter). Studentene skulle utvikle en case med utgangspunkt i en elev de hadde observert i skolen, og diskutere casen i lys av teori i en skriftlig oppgave på campus, etter praksisperioden. Jahreies (2010) studie viste at det å transformere en observasjon fra en praktisk situasjon i klasserommet til en teoretisk refleksjon, bød på utfordringer nettopp fordi redskapene som ble brukt, tolkes og endres av deltakerne i situasjonen. Likeledes viste studien at det ikke var en klar sammenheng mellom de vitenskapelige begrepene studentene tok i bruk, og studentenes erfaringer fra den praktiske situasjonen. Studien viste hvordan studentene går gjennom kompliserte og tidkrevende prosesser når de skal transformere praktisk kunnskap til teoretiske refleksjoner. Jahreie (2010) hevdet at institusjonens tilrettelegging av oppgaven, ga studentene muligheter til en kollektiv orientering $\mathrm{i}$ forhold til både den teoretiske og den praktiske konteksten.

I ytterligere to artikler, analyserte Ottesen og Jahreie (2010a, 2010b) lærerstudenters deltakelse innenfor og på tvers av læringskontekster. Data er hentet fra tre læringskontekster i studiet: teoriundervisningen på campus, samtaler i den praktiske delen av studiet og muntlig eksamen på campus på slutten av studiet. En gruppe på fire studenter ble fulgt gjennom et læringsforløp på ett år. Analyser ble gjort av dialoger mellom studenter, og mellom studenter, lærerutdannere og de ansvarlige for den praktiske delen. De empiriske analysene viste at det tilbys et felles motiv for studentenes læringsforløp, men at læringsforløpene tolkes og konstrueres forskjellig i de ulike kontekstene. Hva som gjaldt som kunnskap innenfor de ulike kontekstene, og hvilke aspekter i aktiviteten deltakerne orienterte og posisjonerte seg i forhold til, var bestemt av interaksjonen, men regulert i relasjonen mellom det sosiale, kulturelle og historiske.

Basert på det samme datamaterialet, drøftet Jahreie og Ottesen (2010b) hvordan lærerstudenter samhandler på tvers av kontekster gjennom lærerutdanningen, med fokus på hvordan grenser mellom kontekstene konstrueres i interaksjoner, hvordan studentene gjør grenser relevante og får konsekvenser for deres læringsforløp. Analysene viste hvordan interaksjoner i "grenselandet” mellom de to kontekstene, fører til begrensninger. Deltakernes meningskonstruksjoner kan således ta forskjellige retninger og ende i motsetninger innenfor og mellom kontekster, blant annet på grunn av historisk utviklede og rigide grenser mellom teoriundervisningen på campus og den praktiske delen av studiet.

Fosse (2011) har studert studenters samtaler på campus og i skolen. Ni studenter ble fulgt gjennom sitt første semester. Her ble samtaler analysert, mellom studentene og lærerutdanner på campus mens de jobbet med en case og mellom studentene og veilederne i skolen etter undervisning. Etter at teorier om læring og utvikling var blitt presentert på campus og lærerstudentene oppfordret til å utvikle vitenskapelig språkbruk, viste dataene at studentene utviklet 
teoretisk kunnskap om læring ved å studere pensumlitteraturen og jobbe med en autentisk case om Mons (en umotivert elev som bruker unngåelsesstrategier). I disse samtalesituasjonene viste studentene hvordan de var i stand til å analysere og forstå begreper om for eksempel motivasjon, analysere casen i lys av teorier om motivasjon og foreslå tiltak for tilpasset opplæring for Mons. I samtalene gjorde studentene fagbegreper til objekter for analyse og resonnerte seg fram til en forståelse av dem. I skolen bar samtalene med veileder preg av å være hverdagslige og med fokus på praktiske aktiviteter fra undervisningen. Til tross for at noen studenter forsøkte å vise til det de hadde lært på campus, gikk samtalene over i hverdagslig tale fordi veileder i liten grad responderte og støttet studentene i deres forsøk. Kunnskap konstruert i samtalene på campus ble altså i svært liten grad tydeliggjort eller hentet fram i veiledningssamtalene i skolen. Det at studentene forsøkte viser imidlertid at det ligger et potensial for transformering av kunnskap mellom kontekstene dersom de andre deltakerne hadde respondert og elaborert videre over fenomenet det ble snakket om.

Oppsummert viser disse studiene hvordan konteksten påvirker lærerstudentens læring. Studentene forhandler innenfor en annen ramme i skolehverdagen enn på campus. Dette innebærer at lærerstudentene skaper mening i omgivelser som tilbyr andre redskaper, kunnskap og erfaringer i skolen enn dem som finnes på campus. Studiene viser at transformering byr på utfordringer nettopp fordi redskapene som brukes, tolkes og endres av lærerstudentene i situasjonen. Mye tyder likevel på at studentene forstår og tar i bruk kunnskap konstruert i andre kontekster, under gitte forutsetninger. De studiene det refereres til her viser videre hvordan case kan gjøre lærerstudentene bedre i stand til å knytte teoretiske prinsipper og begreper til autentiske klasseromssituasjoner, noe flere nasjonale og internasjonale studier også viser (Grossman, 2005; Hauge, 2002; Levin, 1999; Ludvigsen \& Flo, 2002; Nieto, 1999; Pugach, 2005). Case ser dermed ut til å kunne fungere som et viktig redskap i studentenes læringsprosesser og i transformeringen mellom kontekstene.

\section{Diskusjon}

Jeg vil i det følgende diskutere problemstillingen, som spør hvordan vi kan forstå lærerstudenters utfordringer med å transformere kunnskap mellom campus- og skolekontekstene, i lys av litteraturen og forskningen artikkelen støtter seg til.

I et sosiokulturelt perspektiv, transformeres kunnskap når den oppstår i andre praksiser, hvilket betyr at kunnskap får ulike utrykk i ulike kontekster, fordi kunnskapens status og mening er forskjellig, og fordi kunnskapskonstruksjon foregår i ulike kulturer med ulike agendaer og ressurser (Vygotsky, 1978; Wertsch, 1998). I følge Sfard (1998) og Eraut (2004) er læringsprosesser en 
kombinasjon mellom overføring og transformasjon, tilegnelse og deltakelse og mellom individuelle og sosiale prosesser.

De studiene som ligger til grunn for denne artikkelen (Fosse, 2011; Jahreie 2010; Ottesen, 2006; Ottesen \& Jahreie, 2010a, 2010b) viser hvordan tilgjengelige redskaper, spesielt de språklige, og den sosiokulturelle konteksten virker inn på studentenes læring. I hvilken grad de bruker kunnskap fra campus når de snakker om undervisning i skolen er vanskelig å identifisere fordi språket endrer seg under påvirkning fra veileders måte å snakke på, fra et fagspråk etablert på campus til et hverdagslig språk som inneholder få eller ingen fagbegreper (Fosse, 2011).

Transformeringsprosesser er med andre ord komplekse og lærerstudenters kunnskapskonstruksjoner utfordres når det de har lært, for eksempel om motivasjon, skal brukes i nye kontekster. Eraut (2004) hevder at profesjonelle praksiser som lærutdanninger ikke er opptatt av hva som foregår i transformeringsprosessene, og heller ikke hjelper studentene i disse prosessene. Den forskning det er vist til i denne artikkelen bekrefter langt på vei dette, fordi den tyder på at studentene på egen hånd må transformere kunnskap fra campus til undervisning, og til refleksjon over undervisning, i skolen. Lærerstudenters rapportering om manglende sammenheng mellom det som skjer på campus og $\mathrm{i}$ skolen kan blant annet ha sitt utspring i manglende hjelp til å transformere og integrere relevant kunnskap i nye situasjoner (NOKUT, 2006; 2013). Et spørsmål som kan stilles i den sammenheng er $i$ hvilken grad partnerskapsmodellene og metodene som brukes i lærerutdanningen tar hensyn til at kunnskap må transformeres når studentene skal bruke den i andre kontekster.

Som nevnt, er lærerutdanninger preget av ideen om kunnskap for praksis, som innebærer at studentene forventes å overføre eller transformere sine teoretiske kunnskap og erfaringer til praksis i klasserommet (Aasen, 2008; Cochran-Smith \& Lytle, 1999; Korthagen, 2008). I det reformarbeidet som mange lærerutdanninger etablerer, er en av de viktigste hensiktene nettopp å lette studentenes transformeringsprosesser. Siden det i hovedsak er campuskonteksten som utvikler metodene og gjennomfører undervisningen som skal lette transformeringen foregår disse prosessene i hovedsak på campus og det blir fortsatt studentenes oppgave å transformere kunnskapen og tilpasse den til skolekonteksten. Dette ansvarliggjør studenten på en måte som kan hindre eller forsinke profesjonell utvikling, inkludert et felles fagspråk (Haug, 2008).

Det å anerkjenne at kunnskap om undervisning handler om både teoretisk, praktisk og erfaringsbasert kunnskap, vil kunne utfordre den tradisjonelle teoripraksis tenkningen og samarbeidet mellom campus og skole. Diskusjoner om pedagogikkens rolle i lærerutdanningen og hvordan faget kan gjøres relevant for skolen blir viktige i denne sammenhengen (Haug, 2010). Videre bør spørsmålet om hvorvidt det er mulig å avskaffe spenningen mellom teori og praksis eller hvordan man kan leve med den, drøftes. Med andre ord blir lærerutdanningen 
utfordret til å stille grunnleggende spørsmål om hvor og hvordan kunnskap om undervisning best konstrueres, for eksempel som kunnskap for praksis, $i$ praksis eller fra praksis (Cochran-Smith \& Lytle, 1999) - eller i en integrering mellom disse.

I tillegg er det klare indikasjoner på at kontekstene i lærerutdanningen jobber innenfor grenser som på flere områder er fastlagte og kan fremstå som lukkede (Lillejord \& Børte, 2014). At kontekster kan oppleves som lite gjennomtrengelige kan nettopp ha sammenheng med at kontekster oppstår i situasjoner mellom menneskene, redskapene og de spesielle aktivitetene som foregår der. Hensikten formes med andre ord innenfor de praksisene der hensikten oppstår (Edwards, 2010). Dette skaper utfordringer med hensyn til å utvikle partnerskap, som både skal gi innsikt i den aktuelle konteksten og kunne ta del i felles kunnskapsutvikling. Sett i lys av et sosiokulturelt perspektiv på læring og hvordan kontekster utvikles, vil en løsning kunne være å opprette en helt ny kontekst i nærheten av de opprinnelige grensene (Edwards, 2010), med deltakere fra campus og skole der alle transformerer sin kunnskap til et felles prosjekt. I et slikt samarbeid anerkjennes alles kunnskap og bidrag, og det utvikles oppgaver og metoder som har som grunnlag å skape sammenheng i lærerutdanningen, for lærerstudentene.

Lillejord og Børte (2014) tar, som nevnt, i sin forskningsrapport et oppgjør med den tradisjonen vi har i dag og etterlyser en ny måte å tenke på når det gjelder partnerskapsmodeller. Det er mye som tyder på at utfordringer i lærerutdanningen i liten grad diskuteres i lys av studier om hva som skjer i lærerstudenters læringsprosesser.

\section{Avsluttende kommentar og videre forskning}

Denne artikkelen problematiserer lærerstudenters læringsprosesser og spesielt transformeringsprosessene som skjer når studentene beveger seg mellom campus og skole, og antyder at kunnskap om lærerstudenters læringsprosesser må tas i betraktning når for eksempel ulike partnerskapsmodeller og metoder utvikles i lærerutdanningen. Artikkelen spør blant annet om manglende fokus på hva som faktisk skjer i lærerstudenters lærings- og transformeringsprosesser kan være medvirkende årsak til at lærerstudenter fortsatt opplever svak sammenheng mellom aktivitetene på campus og i skolen.

For bedre å forstå lærerstudenters utfordringer med å knytte sammen campusaktiviterer og skoleaktiviteter er det behov for forskning som i større grad ser på hvordan lærerstudenter konstruerer og transformerer kunnskap i lærerutdanningens ulike kontekster. Det innebærer også studier av de kontekstene læringen konstrueres i, de redskapene som tilbys og hvordan veiledere i skolen og lærerutdannere på campus bidrar til lærerstudenters læring og utvikling. 


\section{Referanser}

Aasen, P. (2008). Lærerutdanningen ved universiteter og høyskoler. Utdanningspolitiske perspektiver. I Knudsen, G. \& Evenshaug, T. (red.), Universitetet og læererutdanningen. Historiske perspektiver (s. 239-254). Oslo: Unipub.

Afdal, H. W. (2014) Fra politikk til praksis - konstruksjon av læreres profesjonelle kunnskap. Norsk pedagogisk tidsskrift, 98, 469-481.

Anderson, J. R., Greeno, J. \& Simon, H. A. (2000). Perspectives on Learning, Thinking, and Activity. Educational Researcher, 29(4), 11-13.

Borko, H., Whithcomb, J. A., \& Byrnes, K. (2008). Genres of research in teacher education. I Cochran-Smith, M., Feiman-Nemser, S., McIntyre, D. J., \& K. E. Demers (red.). Handbook of research on teacher education. Enduring Questions in Changing Contexts (s. 1017- 1050). New York: Routledge.

Childs, A., Edwards, A., \& McNicholl, J. (2014). Developing a Multi-Layered System of Distributed Expertise: What does Cultural Historical Theory Bring to Understandings of Workplace Learning in School-University Partnerships? I McNamara, O., Murray, J., \& Jones, M. (red.). Workplace Learning in Teacher Education. International Practice and Policy (s. 29-54). Dordrecht: Springer.

Cochran-Smith, M. \& Demers, K. E. (2008). How do we know what we know? Research and teacher education. I Cochran-Smith, M., Feiman-Nemser, S., McIntyre, D. J., \& Demers, K. E. (red.). Handbook of research on teacher education. Enduring Questions in Changing Contexts (s. 1009-1016). New York: Routledge/Taylor \& Francis group and the Association of Teachers Educators.

Cochran-Smith, M. \& Lytle, S. L. (1999). Relationships of Knowledge and Practice: Teacher Learning in Communities. I Iran-Nejad, A. \& Pearson, P. D. (red.), Review of Research in Education, 24 (s. 249-306). Washington, DC: American Educational Research Association.

Darling-Hammond, L. (2008). The case for university-based teacher education. I CochranSmith, M., Feiman-Nemser, S., McIntyre, D. J., \& Demers, K. E. (red.). Handbook of research on teacher education. Enduring Questions in Changing Contexts (s. 333-346). New York: Routledge.

Edwards, A. \& Protheroe, L. (2003). Learning to See in Classrooms: what are student teachers learning about teaching and learning while learning to teach in schools? British Educational Research Journal, 29(2), 227-242.

Edwards, A. (2010). Being an expert professional practioner: The relational term in expertise. Dordrecht: Springer.

Eraut, M. (2004). Transfer of knowledge between education and workplace settings. I Rainbird, H., Fuller, A. \& Munro, H. (Red.), Workplace learning in context (s.201-221). London: Routledge.

Eraut, M. (2014). Developing Knowledge for Qualified Professionals. I McNamara, O., Murray, J., \& Jones, M. (red.), Workplace Learning in Teacher Education. International Practice and Policy (s. 47-72). Dordrecht: Springer.

Fenstermacher, G. D. (1994). The Knower and the known: The nature of knowledge in research on teaching. I Darling-Hammond, L. (red.), Review of Research in Education 20. Washington: American Educational Research Association. 
Fosse, B. O. (2011). Lærerstudenters innramming og forståelse av tilpasset opplcering. En studie av kollektive leringsprosesser i ulike kontekster ved en praktisk-pedagogisk lcererutdanning. Upublisert Doktoravhandling, Universitetet i Oslo, Oslo

Gardner, H. (1985). The Minds New Science. A History of the Cognitive Revolution. New York: Basic Books.

Grossman, P. (2005). Research on Pedagogical Approaches in Teacher Education. I CochranSmith, M, \& Zeichner, K.M. (red.). Studying Teacher Education. The Report of the AERA Panel on Research and Teacher Education. Mahwah, New Jersey: Lawrence Erlbaum Associates.

Grossman, P., Hammerness, K., \& McDonald, M. (2009). Redefining teaching, reimagining teacher education. Teachers and Teaching: Theory and Practice, 15(2), 273-289.

Haug, P. (2008). Norsk lærarutdanning - kva har skjedd med pedgogikkfaget? Norsk pedagogisk tidsskrift, 06, 487-493.

Haug, P. (2010). Kvalifisering til læraryrket. I Haug, P. (red.). Kvalifisering til læararyrket (s. 9-28). Oslo: Abstrakt forlag.

Haugan, J. A. (2014). Student teachers' tool orientation during internships. Tidsskriftet FoU i praksis, 8(2), 29-49.

Hauge, T. E. (2002). Casearbeid og mappevurdering som integreringsverktøy i lærerutdaningen. I Ludvigsen, S. \& Hoel, T. L. (red.). Et Utdanningssystem i Endring: IKT og Læring (s. 149-172). Oslo: Gyldendal Akademisk.

Jahreie, C. F. (2010). Making sense of conceptual tools in student-generated cases: Student teachers' problem-solving processes. Teacher and teacher education,26(6), 1229-1237.

Jahreie, C. F. \& Ottesen, E. (2010a). Learning to become a teacher. Participation across spheres for learning. I Ellis, V., Edwards, A., \& Smagorinsky, P. (red.), CulturalHistorical Perspectives on Teacher Education and Development. Learning Teaching (s. 131-146). London: Routledge

Jahreie, C. F. \& Ottesen, E. (2010b). Construction of boundaries in teacher education: Analyzing student teachers' accounts'. Mind, Culture, and Activity, 17(3), 212-234.

Karlsen, G. E. (2003). Hvorfor en bok om lærerutdanning? I Karlsen, G. E. \& Kvalbein, I. A. (red.), Norsk lærerutdanning. Søkelys på allmennlærerutdanningen i et reformperspektiv ( s.13-23). Oslo: Universitetsforlaget.

Klette, K. \& Hammerness, K. (2016). Conceptual Framework for Analyzing Qualities in Teacher Education: Looking at Features of Teacher Education from an International Perspective. Acta Didactica Norge, 10(2), 26-53.

Korthagen, F. A. J. (2008). Linking Practice and Theory. The Pedagogy og Realistic Teacher Education. New York: Routledge.

Lambert, P. (2003). Promoting Developmental Transfer in Vocational Teacher Education. I Tuomi-Gröhn, T. \& Engeström, Y. (red.). Between School and Work: New perspectives on transfer and boundary-crossing (s. 233-254). Amsterdam: Pergamon.

Lave, J. \& Wenger, E. (1991). Situated Learning: Legitimate Peripheral Participation. New Jersey: Cambridge University Press.

Lave, J. \& Wenger, E. (2003). Situert Læring og andre tekster. København: Hans Reitzels Forlag.

Levin, B. B. (1999). The Role of Discussion in Case Pedagogy: Who Learns What? And How? I Lundeberg, M. A., Levin, B. B., \& Harrington, H. L. (red.), Who Learns What From Cases and How. The research base for teaching and learning with cases (s. 139157). Mahwah, New Jersey: Lawrence Erlbaum Associates.

Lillejord, S. \& Børte, K. (2014). Partnerskap i læererutdanningen. En forskningskartlegging KSU 3/2014. Hentet fra 
http://www.forskningsradet.no/servlet/Satellite?c=Rapport\&cid=1254003899070\&lang=n o\&pagename=kunnskapssenter\%2FHovedsidemal

Ludvigsen, S. \& Flo, C. F. (2002). Innovasjon i Lærerutdanningen: Hvordan Skapes Endring? I Ludvigsen, S. \& Hoel, T. L. (red.). Et Utdanningssystem i Endring: IKT og Læring. Oslo: Gyldendal Akademisk.

Lund, A., Jakhelln, R., \& Rindal, U. (2015). Fremragende lærerutdanning - hva er det, og hvordan kan vi få det? I Rindal, U., Lund, A., \& Jakhelln, R. (red.). Veier til fremragende lærerutdanning (s. 13-31). Oslo: Universitetsforlaget.

Nieto, S. (1999). Culturally Relevant Teaching With Cases: A personal Reflection and Implications for Pedagogy. I. Lundeberg, M. A., Levin, B. B., \& Harrington, H. L. (red.), Who Learns What From Cases and How. The research base for teaching and learning with cases (s. 179-196). Mahwah, New Jersey: Lawrence Erlbaum Associates.

NOKUT. (2006). Evaluering av allmennlærerutdanningen i Norge 2006. Del 1: Hovedrapport. Hentet fra http://www.nokut.no/Documents/NOKUT/Artikkelbibliotek/Norsk_utdanning/Evaluering lalueva/ALUEVA_Hovedrapport.pdf

NOKUT. (2013). PPUs relevans av studenters og nyutdannede læeres oppfatninger. Rapport, 2013-3. Oslo: Nasjonalt organ for kvalitet i utdanningen.

Ottesen, E. (2006). Talk in practice. Analysing student teachers' and mentors'discourse in internship. Upublisert Doktoravhandling, Universitetet i Oslo, Oslo

Packer, M. J. \& Goicoechea, J. (2000). Sociocultural and Constructivist Theories of Learning: Ontology, Not Just Epistemology. Educational Psychologist, 35(4), 227-241.

Pugach, M. C. (2005). Research on Preparing General Education Teachers to Work With Students With Disabilities. I Cochran-Smith, M. \& Zeichner, K. M. (red.). Studying Teacher Education. The Report of the AERA Panel on Research and Teacher Education (s. 549-590). Mahwah, New Jersey: Lawrence Erlbaum Associates.

Säljö, R. (2006). Læring og kulturelle redskaper. Om læreprosesser og den kollektive hukommelsen. Oslo: Cappelen Akademisk.

Sfard, A. (1998). On two Methaphors and the Danger of Choosing Just One. Educational Researcher, 27(2), 4-13.

Smeby, J. C. (2010). Studiekvalitet, praksiskvalitet og yrkesrelevans. I Haug, P. (red.). Kvalifisering til leraryrket (s. 98-117). Oslo: Abstrakt forlag.

Sundli, L. (2001). Veiledning i lererutdanningens praksis - mellom refleksjon og kontroll. $\mathrm{HiO}$ rapport no. 15. Oslo: Høgskolen i Oslo og Akershus.

Sundli, L. (2003). Yrkeskvalifisering gjennom praksis. I Karlsen, G. E \& Kvalbein, I. A. (red.). Norsk lcererutdanning. Søkelys på allmennlcererutdanningen i et reformperspektiv (s. 223-238). Oslo: Universitetsforlaget.

Vera, A. H. \& Simon, H. A. (1993). Situated Action: A Symbolic Interpretation. Cognitive Science, 17(1), 7-48.

Vygotsky, L. S. (1978). Mind in Society. The development of Higher Psychological Processes. Cambridge, MA: Harvard University Press.

Vygotsky, L. S. (2001). Tenkning og tale. Oslo: Gyldendal Akademisk.

Wertsch, J. V. (1998). Mind as Action. New York: Oxford University Press. 